\title{
Lymph Node Biopsies: A Hospital Based Retrospective Study
}

\author{
Shrestha AK, ${ }^{1}$ Chalise PR, ${ }^{2}$ Shrestha $\mathrm{ML}^{2}$ \\ 'The Royal Marsden Hospital, London, UK ²Department of Surgery, Nepal Medical College Teaching Hospital, Jorpati, \\ Kathmandu, Nepal.
}

\section{ABSTRACT}

Introduction: Lymphadenopathy is a common clinical finding at the outpatient setting that may be caused by a vast array of disease processes.

Methods: A retrospective study to analyze the histopathological diagnosis of lymph node biopsies with respect to age, sex, and site was conducted. All the lymph nodes sent for histopathological examination from August 2003 to 2007 were included.

Results: Of all patients with enlarged lymph nodes, $49 \%$ were males (mean age: 34.52 years) and $51 \%$ were females (mean age: 38.1 years). The most common diagnosis was tubercular lymphadenitis (42\%), followed by non-specific (reactive) lymphadenitis (23\%), metastatic deposits (10\%), non-specific granuloma (3\%), NHL (2\%), and lymphadenitis due to various other causes $(7 \%)$. Thirteen percent of the biopsied lymph nodes were normal in morphology. Most common site of lymph node enlargement was neck $(44 \%)$ followed by mesentery $(19 \%)$ and axilla $(16 \%)$. Most of the patients were in the age group of 21-30 years (20\%).

Conclusions: The neck lymph nodes were the most commonly sent nodes for histopathological examination and tuberculosis was the most common diagnosis.

Key Words: cancer, cervix, endometrium, ovary, vagina, vulva

\section{INTRODUCTION}

Lymphadenopathy is defined as an abnormality in the size or character of lymph nodes caused by the invasion or propagation of either inflammatory cells or neoplastic cells into the node. It results from a vast array of disease processes and among the serious illnesses that can present with lymphadenopathy, perhaps the most concerning to the patient and physician alike is the possibility of underlying malignancy. ${ }^{1,2}$
Correspondence:

Dr. Manohar Lal Shrestha

Department of Surgery

Nepal Medical College and Teaching Hospital

Jorpati, Kathmandu, Nepal.

Email: drmlshr@yahoo.com

Phone: 9851083343 
Lymphadenopathy is classically described as a node larger than $1 \mathrm{~cm}$, although this varies by lymphatic region. Palpable supraclavicular, iliac, or popliteal nodes of any size and epitrochlear nodes larger than $5 \mathrm{~mm}$ are considered abnormal. ${ }^{3,4}$ There is no uniform nodal size at which one should become suspicious of a neoplastic etiology. ${ }^{5,6}$ Increasing size and persistence over time are of greater concern for malignancy than a specific level of nodal enlargement and many a time biopsy is required for final histopathological diagnosis.

\section{METHODS}

A retrospective study was conducted at Nepal Medical College Teaching Hospital between August 2003 and August 2007 including the cases of progressively enlarging and/or persistent lymph nodes that had been biopsied. Institutional approval was taken. The total number of cases was 100. Diagnosis made on the FNAC or other methods were excluded from the study. Biopsies from superficial lymph nodes (e.g. cervical, axillary and inguinal) as well as mesenteric lymph nodes and the ones sent as part of main specimen such as in surgery of bowel, gall bladder, breast were included. Results were interpreted with respect to age, sex azand site of lymphadenopathy on the basis of histopathological diagnosis. Data were analyzed using the Statistical Package for Social Sciences (SPSS) version-12 for windows.

\section{RESULTS}

Of all the patients $(n=100)$ who underwent lymph node biopsy, $49 \%$ were males (34.52 \pm 22.39 years) and $51 \%$ were females $(38.10 \pm 18.36$ years), male to female ratio being $0.96: 1$. Most of the patients were in the age group of $20-29$ years (20\%) followed by $10-19$ years $(18 \%)$ and more than 60 years $(15 \%)$. Fourteen percent of the patients were in the age group of 40-49 years, $12 \%$ each in $30-39$ and $50-59$ years age group and only $9 \%$ in $0-9$ years age group. Amongst males, maximum number of cases was in the age group of 2029 years $(26.5 \%)$ followed by $10-19$ years age group $(16.3 \%)$ while amongst females, maximum number of cases were in the age group of $40-49$ years $(21.6 \%)$ followed by $10-19$ years age group (19.6\%) (Figure 1, Table 1).
Table 1. Distribution of disease with respect to age

\begin{tabular}{lllllllll}
\hline $\begin{array}{l}\text { Age } \\
\text { group }\end{array}$ & $\begin{array}{l}\text { TB } \\
\text { LA }\end{array}$ & $\begin{array}{l}\text { Reactive } \\
\text { (NS) LA }\end{array}$ & $\begin{array}{l}\text { Mets } \\
\text { NHL Granuloma }\end{array}$ & $\begin{array}{l}\text { Others } \\
\text { (NS) }\end{array}$ & $\begin{array}{l}\text { Normal } \\
\% \\
\text { LNs }\end{array}$ \\
\hline $0-9$ & - & 3 & - & - & 1 & 3 & 2 & 9 \\
$10-19$ & 10 & 5 & - & - & - & 2 & 1 & 18 \\
$20-29$ & 14 & 3 & - & - & 1 & 1 & 1 & 20 \\
$30-39$ & 62 & & 1 & - & - & - & 3 & 12 \\
$40-49$ & 7 & 1 & 2 & - & - & - & 4 & 14 \\
$50-59$ & 2 & 6 & 3 & & & 1 & - & 12 \\
$>60$ & 3 & 3 & 4 & 2 & - & 1 & 2 & 15 \\
Total & 42 & 23 & 10 & 2 & 3 & 7 & 13 & 100 \\
\hline
\end{tabular}

TB - Tuberculosis, LA - Lymphadenopathy, NS - Nonspecific, Mets - Metastatic deposits, NHL - Non Hodgkin's Lymphoma, LNs - Lymphnodes

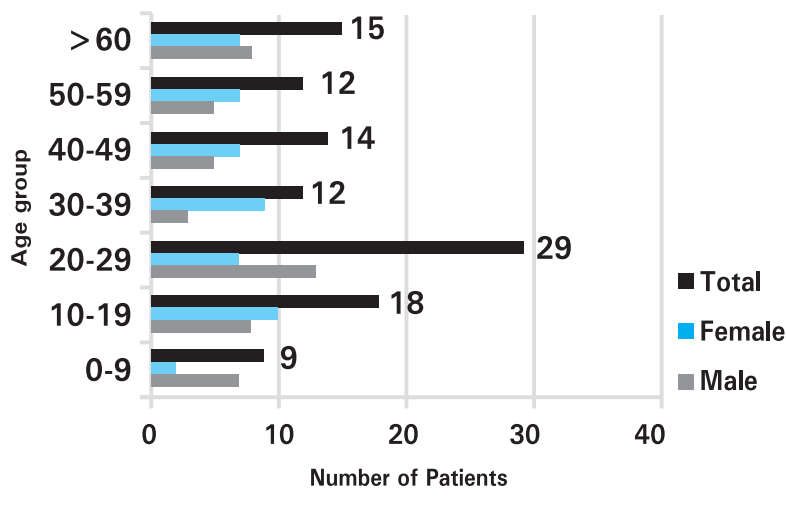

Figure 1. Age and sex distribution of the patients $(n=100)$

Forty nine percent of the nodes were from the neck region, $19 \%$ from the mesentery, $16 \%$ from the axilla, and $7 \%$ from the inguinal region. Nine percent of the nodes were received as part of main specimen (perivisceral) of bowel, GB, breast and thyroid (Table 2).

Table 2. Distribution of disease with respect to site

\begin{tabular}{|c|c|c|c|c|c|c|c|c|}
\hline $\begin{array}{l}\text { Site of } \\
\text { LAP }\end{array}$ & $\begin{array}{l}\text { TB } \\
\text { LA }\end{array}$ & $\begin{array}{l}\text { Reactive } \\
\text { (NS) LA }\end{array}$ & Mets & NHL & $\begin{array}{l}\text { Granul- } \\
\text { oma(NS) }\end{array}$ & Others & $\begin{array}{l}\text { Normal } \\
\text { LNs }\end{array}$ & $\%$ \\
\hline Neck & 27 & 11 & 2 & 1 & 2 & 3 & 3 & 49 \\
\hline Mesentery & 9 & 4 & 1 & - & - & 2 & 3 & 19 \\
\hline Axilla & 5 & 5 & 1 & 1 & 1 & 1 & 2 & 16 \\
\hline Perivisceral & |- & 1 & 5 & - & - & - & 3 & 9 \\
\hline Inguinal & 1 & 2 & 1 & - & - & 1 & 2 & 7 \\
\hline Total & 42 & 23 & 10 & 2 & 3 & 7 & 13 & 100 \\
\hline
\end{tabular}

LA - Lymphadenopathy, TB - Tuberculosis, NS - Nonspecific, Mets - Metastatic deposits, NHL - Non Hodgkin's Lymphoma, LNs - Lymphnodes. 
Forty two percent showed microscopic findings consistent with tubercular lymphadenitis, $23 \%$ showed findings of reactive lymphadenitis, and $13 \%$ showed morphology of normal lymph node. Findings of metastatic deposit were seen in $10 \%$ of the lymph nodes. Two cases each of $\mathrm{NHL}$, dermatopathic lymphadenopathy, and fibrotic lymphadenopathy were reported. One case each of acute necrotizing lymphadenopathy, LN with extensiv hemorrhagic areas, and LN with abscess and hemorrhage was also noted (Figure 2).

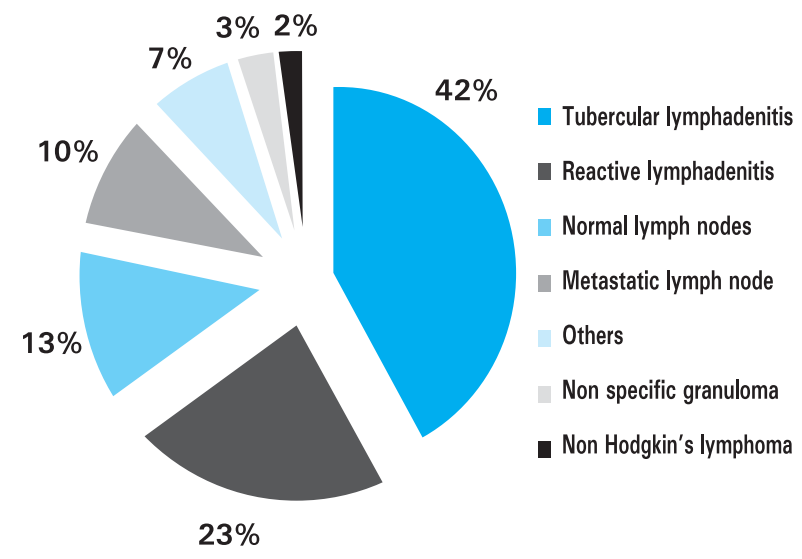

Figure 2. Histopathological diagnosis of lymph node biopsies

Histopathological diagnosis of tuberculosis was made in 42 cases $(42 \%)$ of which twenty six cases were females $(61.9 \%)$ and 16 cases $(38.1 \%)$ were males, male to female ratio being 1:1.62. Mean age was $32.95 \pm 16.130$. Most of the patients were in the age group of $20-29$ years $(33.3 \%)$ followed by $10-19$ years $(23.8 \%)$ and $40-49$ years $(16.7 \%)$. There were no cases of tuberculosis in the age group of 0 9 years $(0 \%)$.

Neck was the most common site $(64.7 \%)$, followed by mesentery (9\%), axilla (5\%) and inguinal region $(1 \%)$. Regarding metastatic deposits in the lymph nodes, $90 \%$ were above the age of 40 years and $40 \%$ of these nodes were the ones sent along with gastrectomy specimen. There were two cases of $\mathrm{NHL}$ both of which were males above the age of 60 years. Amongst the three cases of granulomatous enlargement of lymph nodes, one showed histopathological findings consistent with atypical mycobacterial infection and the rest two showed findings suggestive of fungal granuloma.

\section{DISCUSSION}

Lymph node enlargement may occur because of proliferation of cells of the lymphocyte and monocyte-macrophage system usually in response to antigenic stimulus or infiltration by inflammatory cells in infections involving lymph nodes (lymphadenitis), in situ proliferation of malignant lymphocytes or macrophages, infiltration of lymph nodes by metastatic malignant cells or infiltration of lymph nodes by metabolite laden macrophages in lipid storage diseases.? Analysis of lymphadenopathy in primary care practice has shown that more than two-third of patients have non-specific causes or upper respiratory illnesses (viral or bacterial), and less than $1 \%$ have malignancy. ${ }^{8}$ In one study, 186 of 220 patients (84\%) referred for evaluation of lymphadenopathy had a benign diagnosis. One hundred and twelve of 186 $(63 \%)$ patients with benign lymphadenopathy had a nonspecific or reactive etiology (no causative agent found) and the remainder had a specific cause. ${ }^{9}$ Similarly, in other series, the percentage of above findings ranged from $35.6 \% 1614$ of 1724 patients) to $65.6 \%$ (164 of 250 patients). ${ }^{7,10}$ In present study only $23 \%$ lymph node biopsies showed nonneoplastic non-infectious reactive lymphadenopathy while in the rest there were identifiable causes demonstrated. One study showed maximum number of patients in the age group of $10-30$ years (55.2\%) which is similar to our study though the percentage is low $(38 \%))^{7}$

Tubercular lymphadenitis is still a common cause of cervical lymphadenopathy. The condition most commonly affects children and young adults, but can occur at any age. ${ }^{11}$ The commonest diagnosis in the present study was tubercular lymphadenitis (42\%), most of the patient being in the age group of 10-29 years. A study done by Danpat et al. revealed tuberculosis in $51 \%$ of cases. ${ }^{12}$ Several other studies have also reported high incidence of tuberculosis in biopsied lymphnodes. , 13-18 The commonest site of lymphadenopathy is neck. ${ }^{7,13-16-19}$ In our study $49 \%$ were the neck lymph nodes (69\% of all peripheral lymph nodes) of which $55.1 \%(n=27)$ cases were tuberculosis.

The fourth common diagnosis was metastatic lymph nodes in 10 cases. Ninety percent of the patients were above the age of 40 years which is comparable to other studies. ${ }^{14,17,20}$ Out of remaining ten, four lymph nodes were received along with the main specimen of carcinoma stomach, one with adenocarcinoma of gall bladder. Three lymph nodes were from neck, out of which one was from papillary carcinoma thyroid and the other two from unknown primary site.

\section{CONCLUSIONS}

Neck lymph nodes were the most commonly sent nodes for histopathological examination and tuberculosis was the most common diagnosis. Therefore persistent lymphadenopathy must not be overlooked but evaluated by biopsy. Moreover this study will be a cornerstone for prospective studies to be conducted in the future to establish the etiology and define the age and sex distribution. 


\section{REFERENCES}

1. Ferrer R. Lymphadenopathy: Differential diagnosis and evaluation. Am Fam Physician. 1998;58:1313-20.

2. Andrew WB and Douglas RS. Lymphadenopathy and malignancy. Am Fam Physician. 2002;66:2103-10.

3. Kelly CS and Kelly RE. Lymphadenopathy in children. Paediatric Clin North Am. 1998;45:875-88.

4. Grossman M and Shiramizu B. Evaluation of lymphadenopathy in children. Curr Opin Pediatr.1994;6:68-76.

5. Pangalis GA, Vassilakopoulos TP, Boussiotis VA and Fessas P. Clinical approach to lymphadenopathy. Semin Oncology. 1993;20:570-82.

6. Slap GB, Brooks JS and Schwartz JS. When to perform biopsies of enlarged lymph nodes in young patients. JAMA. 1984;252:1321-6.

7. Chhabra S, Mohan H and Bal A. A retrospective histological evaluation of non-neoplastic superficial lymphadenopathy. [Online] 2006 [Cited 2008 sep];6-1. Available from: http://www.ispub.com/journal/the_internet_journal_of_in ternal_medicine/volume_7_number_2_14/article/a_retrosp ective_histological evaluation_of_non-neoplastic_superficial_lymphadenopathy.html

8. Kubota T. The evaluation of peripheral adenopathy. Prim care. 1980;7:461.

9. Williamson HA. Lymphadenopathy in a family practice: A descriptive study of 240 cases. J Fam Pract. 1985;20:449.

10. Mohan A, Reddy MK, Phaneendra BV and Chandra A. Aetiology of peripheral lymphadenopathy in adults: analysis of 1724 cases seen at a tertiary care teaching hospital in Southern India. Natl Med J India. 2007;20:78-80.
11. Russel RCG, Norman SW and Christopher JKB. Tuberculous adenitis. In: Bailey and Love's short practice of Surgery. 23rd ed. London: Arnold publishers; 2000. P.704.

12. Danpat MC, Mishra BM, Das SP and Kar PK. Peripheral lymph node tuberculosis: a review of 80 cases. British J Surgery. 1990;77:911-2.

13. Adelusola KA, Oyelami AO, Odesanmi WO, and Adeodu OO. Lymphadenopathy in Nigerian children; West Afr J Med. 1996;15:97-100.

14. Olu-Eddo AN and Ohanaka CE. Peripheral lymphadenopathy in Nigerian adults. J Pak Med Assoc. 2006;56:405-8.

15. Okolo SN, Nwana EJ and Mohammed AZ. Histopathologic diagnoses of lymphadenopathy in children in Jos, Nigeria. Niger Postgrad Med J. 2003;10:165-7.

16. Hussain M and Rizvi N. Clinical and morphological evaluation of tuberculous peripheral lymphadenopathy. J Coll Physicians Surg Pak. 2003;13:694-6.

17. Thomas JO, Ladipo JK and Yawe T. Histopathology of lymphadenopathy in a tropical country. East Afr Med J. 1995;72:703-5.

18. Reddy MP, Moorchung N and Chaudhary A. Clinicopathological profile of paediatric lymphadenopathy. Indian J Paediatr. 2002;69:1047-51.

19. Oguz A, Karadeniz C, Temel EA, Citak EC and Okur FV. Evaluation of peripheral lymphadenopathy in children. Paediatr Hematol Oncol. 2006;23:549-61.

20. Darnal HK, Karim N, Kamini K and Angela K. The profile of lymphadenopathy in adults and children. Med J Malaysia. 2005;60:590-8. 